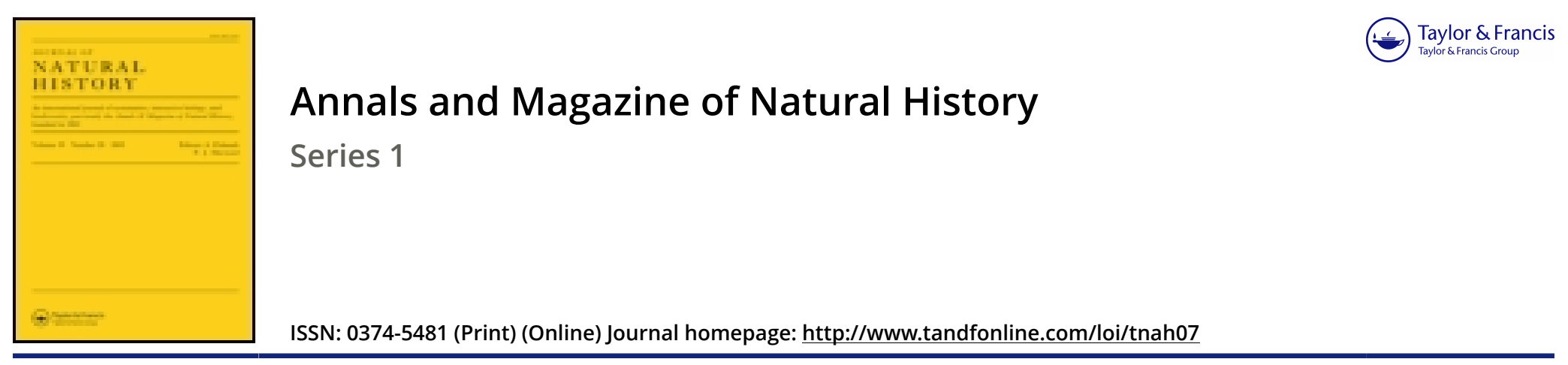

\title{
XVII._On Mucor observed by Col. Montagu growing in the Air-cells of a Bird
}

\section{Wm. Yarrell Esq., F.L.S.}

To cite this article: Wm. Yarrell Esq., F.L.S. (1842) XVII._On Mucor observed by Col. Montagu growing in the Air-cells of a Bird, Annals and Magazine of Natural History, 9:56, 131-132, DOI: 10.1080/03745484209442801

To link to this article: http://dx.doi.org/10.1080/03745484209442801

\section{册 Published online: 04 Dec 2009.}

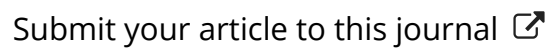

Q View related articles $\longleftarrow$ 
is tile-red. Little spechs of a decper tint of the same colour border each scale, and these specks are at intervals crowded so as to preduce five vertical bands under the soft dorsal, narrower than the intervening spaces. There is another less distinct band on the nape, and a seventh on the base of the caudal. None of the bands go beyond the general line of the red. The lower half of the side is pale primrosc-yellow, which fades to white on the belly. The head, which is represented as scaly on its whole upper surface as well as on the cheeks and gill-covers, is coloured like the body, except that white replaces the yellow of the lower parts. 'Three azure-blue streaks cross the front between the eyes, one on the upper part of the cheek follows the curre of the orbit, two rum from the eye to the upper lip, and two connected like a bent bow and its string, cross the occiput. The spinous dorsal is entirely black, the soft one pale bluish lilac; and behind each ray there are two round white spots, one abeve the other, and two blackish brown dots higher up, making four rows in all. The anal is also lilac, but with a tinge of crimson; and it is marked by a series of sixtcen crimson strcaks running obliquely forwards across the rays. The cauclal is red like the back, with a yellow upper and under border, and four waving transverse lines on its distal half. 'The pectorals are unspotted red, and the ventrals greenish.

['To be continued.]

XVII.-On IIfucor observed by Col. Montagu growing in the Air-cells of a Bird. From Wr. YanneLL, Lsq., F.L.S.

To the Editors of the Annals of Natural IIistory.

\section{Gentlenex,}

Is addition to the instances quoted in the cighth volume of the 'Annals,' page 229, of the growth of cryptogamous plants in the bronchial tubes of a Flamingo, and on the internal surface of the air-cells of an Eider-duck, allow me to refer you to another example mentioned by Col. Montagu in the 'Supplement to his Ornithological Dictionary,' published in 1813, under the article 'Scaup Duck.' The paragraphs are as follows:-

"The cause of death (in this female) appeared to be in the lungs, and in the membrane that separates them from the other viscera; this last was much thickened, and all the cavity within was covered with mucor or blue mould."

"It is a most curious circumstance to find this vegetable production growing within a living animal, and shows that where air is pervious, mould will be found to obtain, if it meets with sufficient moisturc, and a place congenial to vergetation. Now the fact is, that the part on which this vegetable was growing was decayed, and had no longer in itself a living 
principle; the dend part therefore beenme the proper pabulum of the invisible seeds of the mucor transmitted by the air in respiration ; and thus Nature carries on all her works immutably under every possible variation of circumstance. It would indeed be impossible for such to vegetate on a living body, being incompatible rrith vitality, and we may be assured that decay must take place before this minute vegetable can make a lodgement to aid in the great change of decomposition. Even with inanimatc bodies, the appearance of mould or any species of Fungi is a sure presage of partial decay and decomposition."

In your last number, the first of volume nine, Dr. C. Montagne, in his Sketch of the Class Fungi, says, page 10, "The IIyphomycetes grow on vegetable or animal substances in the course of decomposition." I refer to this only to show that Col. Montagu was well acquainted with the conditions necessary to this singular formation.

$$
\text { I am, yours very truly, }
$$

WM. YARREIL.

Ryder Street, St. James's, Marelı 18, 1812.

XVIII.-A List of Invertebrala found in Dublin Bay and its vicinily. By Artirur Hind Hassand, Esq., M.R.C.S.L., Corresponding Nember of the Dublin Natural IIistory Society.

Thr: few invertebrate animals contained in the following list were found by me during the winter of 1840 and spring of 1841. 'The Porifera and Conchifera, with but two exceptions, are purposely excluded from it; examples of the first which I have met with having been sent to Dr. G. Johnston, and most if not all the species of the latter collected by me hare doubtless been previonsly found, though not yet recorded, by that zealous collector T. WV. Warren, lisq. For the Echinodermata the nomenclature of l'orbes is adopted, and for the Crustacen that of Leach.

\section{Echinodermata.}

Comatula rosacea, very abundant in the channcl between Dalkcy Island and the mainland. The marking and colouring of young specimens obtained off Kingstown Iarbour are very beautiful and delicate, very different from the coarse red colour which distinguishes them in their mature condition. I have collected specimons, the diameter of which when expandecl did not exceed hitlf an inch, and in them no trace of footstalks was to be detected. 